\title{
Bilgi Merkezlerinin Yönetiminde Bilgi Sistemlerinin Rolü
}

\author{
The Effect of Information Systems on Information Centers' \\ Management
}

\section{Hakan ANAMERiç ${ }^{\star}$}

\begin{abstract}
Öz
Bilgi merkezleri birer organizasyon olduklarına göre, bilimsel yönetim yaklaşımındaki ilerlemeler, bilgi merkezlerinin örgütsel gelişimleri için de kullanışlı olabilecek sonuçlar ortaya koyarlar. Çalışmada, bu açıdan göz önüne alındıklarında, sistem analizi, toplam kalite yönetimi, halkla ilişkiler, bilgi sistemleri ve bilgi yönetimi yaklaşımlarının, bilgi merkezleri için geçerlilikleri incelenmektedir.
\end{abstract}

Anahtar sözcükler: Bilgi sistemleri, Yönetim bilgi sistemleri, Karar destek sistemleri, Veri işlem sistemleri, Kütüphane yönetimi, Bilgi merkezleri.

\begin{abstract}
Since information centers are organisations, whatever improvements were achieved in the scientific management approaches for the sake of organisational development should also have some suitable counterparts for the establishment and development of information centers. In this respect, concepts of systems analysis, total quality management, public relations, information systems and information management were investigated in terms of their validity by their applications concerning the information centers.
\end{abstract}

Keywords: Information systems, Management information systems, Decision support systems, Data processing systems, Library management, Information centers.

\footnotetext{
* Arş. Gör.; Ankara Üniversitesi Dil ve Tarih-Coğrafya Fakültesi Bilgi ve Belge Yönetimi Bölümü Sıhhiye 06100 Ankara (anameric@humanity.ankara.edu.tr).
} 


\section{Giriş}

Bilgi merkezleri, Frederich W. Taylor'un geliştirmiş olduğu bilimsel yönetim yaklaşımının ilkelerine göre, birer organizasyondur (örgüt) ve tümü bir işletme gibi yönetilebilir. Organizasyon, bir grup insanın belirlenmiş amaçlar ve hedefler doğrultusunda güç birliği yapıp, fiziksel gücünü ve elinde bulundurduğu araçları kullanarak, belirli bir yönetim anlayışı içerisinde bir sistem meydana getirir. Herhangi bir örgütün işletme olabilmesi için yeterli olan özellik, gereksinim duyulan herhangi bir mal veya hizmet üretmek üzere bir ya da birkaç üretim elemanının bir araya getirilmesidir. Bilgi merkezleri de genel olarak kâr amacı gütmeyen ve hizmet üreten kurumlar olarak yukarıda belirtilen özelliği taşımaktadır. Bu bağlamda, birer organizasyon olan bilgi merkezleri de işletme olarak kabul edilebilir ve sözü edilen yaklaşımın sonuçlarından yararlanabilirler.

Bu çalışmada kullanılan bilgi merkezi terimi, tüm kütüphane türlerini kapsamaktadır.

\section{Bilgi Merkezlerinde Yönetim ve Yöneticilerin Bilgi Gereksinimi}

Bilgi merkezleri türlerinden biri olan kütüphanelerin yönetimi ile ilgili olarak değişik ve ilginç bir yaklaşıma Umberto Eco'nun ünlü "Gülün Adı - The Name of the Rose" romanında karşılaşılabilir. Romandaki yaklaşıma göre, kütüphane yönetiminde dikkat çekici dört nokta vardır. İlki, kütüphaneye ve onun kaynaklarına sınırlı erişim; ikincisi, kütüphanedeki kitapların karmaşık bir labirentte saklanması; üçüncüsü, kitaplar için hazırlanmış olan katalog ve indekslerin karmaşık olması ve sadece kütüphaneciler tarafından kullanılabilmesi; dördüncü ve en önemlisi ise, toplumsal düzeni sağlayan itaat, korku, ölüm gibi etkenlerin ilk üç maddenin korunmasında etkili olmasını sağlamaktır. Bu yönetim anlayışı, romanın sonunda kütüphanenin bütünüyle yanması ile sona ermiş ve o toplumdaki belirli bir düşünce sisteminin hakim olduğu bir dönemde gerçekleşmiştir. Günümüzde, özellikle bilimsel yönetim anlayışında önemli değişiklikler ve gelişmeler yaşanmaktadır (Anameriç, 2003, s. 187).

Sözü edilen gelişmelerden en çok etkilenenler ise yöneticiler olmaktadır. Yönetici, örgütün amaçlarına ulaşması için uygun ortamın yaratılmasını sağlar, bu amacı gerçekleştirmek için, gerekli personeli seçer, eğitir, iş ve görev ilişkilerini ayarlar, yapılacak tüm faaliyetleri planlar, yönetir ve kontrol eder. Günümüzde yöneticiler gelişen teknolojinin desteği ile birçok olanaktan daha hızlı ve ucuz biçimde yararlanabilmektedir. Teknolojinin yöneticilere sağlamış olduğu en önemli özelliklerinden biri, bilgiye önem vermesi ve bilgiden nasıl yararlanması gerektiğini bilmesidir. Yöneticilerin temel görevlerinden olan karar verme süreci, yöneticilerin sahip olduğu bilgi desteği ile 
daha etkili, verimli ve gelecekte olası sorunların daha kolay biçimde çözümüne yönelik olarak gerçekleştirilebilecektir.

Yöneticilerin organizasyonun yönetimi için gereksinim duyduğu bilgi üç ana grupta sınıflanabilir: Bunlar; stratejik yönetim, denetim ve işlem bilgisidir. Stratejik yönetim bilgisi, örgütün uzun vadeli amaç ve hedeflerinin, amaçlara ulaşmada gereken kaynak çeşitlerinin ve miktarlarının belirlenmesine yardımcı olmasının yanısıra, kaynakların elde edilmesi ve kullanımında üst kademe yöneticilerinin karar almasını sağlayan stratejik yönetim bilgisi, büyük bir oranda organizasyon dışından elde edilir. Dış kaynaklardan elde edilen bilgiler, iç bilgiler ile beraber işlenerek, gelecekteki faaliyetlerinin planlanmasında ve olası problemlerin çözümlenmesinde kullanılır. Denetim bilgisi, yöneticilere örgüt faaliyetlerinin en üst düzeye çıkarılmasında yardımcı olmasının yanısıra, orta vadeli amaç ve hedefler için gereklidir. Yöneticilere, personel, hammadde, enerji ve mali kaynakların organizasyon amaçları doğrultusunda etkin ve verimli bir şekilde kullanıp kullanmadığını gösterir. İşlem bilgisi ise, organizasyonların kısa vadeli işlemleri ile ilgilidir, belirli (rutin) işlemlerin etkili ve verimli bir şekilde yapılmasına yardımcı olur (Massie, 1983, ss. 174-175). Bu makalede çalışmanın konusu gereği, yönetim bilgisi üzerinde daha fazla durulacaktır.

Yönetim bilgisi, bir işin yerine getirilebilmesi için değil, etkinliklerin denetimi ve geliştirilmesi için gereklidir. Bu tip bilginin en önemli özelliği doğrudan erişiminin çok nadir olması, fakat diğer bilgilerden, özellikle işletim bilgisinden sonuç çıkarılarak elde edilebilmesidir (Uçak, 2000, s. 154; Adams, 1995, s. 11). Yönetimde bilgi, belirli amaçlara ulaşmak veya belirli bir anlayışı geliştirmek için veri veya ham bilginin işlem sonucunda yöneticilere yararlı biçime dönüştürülmüş şeklidir. Başka bir deyişle; yönetim bilgisi, raporlar halinde üst kademelere iletilen, emirler şeklinde alt kademelere aktarılan, günlük faaliyetler aracılığı ile kurumların işlevsel bölümlerini birbirine bağlayan bir olgudur. Bilimsel, entelektüel, güncel, yönetsel gibi çeşitli türlerde üretilmiş olan bilginin boyutları, farklı alanlarda hizmet veren kurumlara önemli ölçüde kolaylık sağlamaktadır. Organizasyonlar, bu bilgi yığını içerisinde kendilerinin gereksinim duydukları bilgiye kısa sürede erişmek istemektedirler. Genel olarak organizasyonlarda bilgiye, yaşanmış deneyimleri gözden geçirmek, bugünü değerlendirebilmek ve yarın ne olabileceğini kestirip planlama yapmak için gereksinim vardır. Ancak bu şekilde büyüyen ve çeşitlenen bilgi yığınlarını anlamak, yorumlamak ve katkıda bulunmak zaman kaybına yol açmaktadır (Anameriç, 2003, ss. 18-19).

Bilgi, yönetim kademelerinde, etkili ve verimli kararlar almak, kurumun işlem süreci içerisinde yararlanmak ve özellikle içinde bulunduğu zor durumlardan en az zararla kurtulmasını sağlamak amacıyla kullanılmaktadır. 
Bu süreç göz önüne alındığında bilginin, organizasyonlar için stratejik ve yaşamsal bir rol oynadığı görülmektedir. Bilgi, kişi ve/veya kurumların planladıkları fikirleri ve faaliyetleri destekleyip birleştirerek bir işi meydana getirir ve böylece soyut anlamdan çıkıp somut bir davranış haline gelir. Bilginin somut bir davranış haline gelmesi, karar verme sürecinin başlaması ve kararın ortaya çıkmasına yol açar. Etkili bir yönetimde bilgi, karar verme amacına yönelik olarak toplanmış verilerin işlenmiş biçimidir.

Yönetim kademelerinin karar verme sürecinde yararlandığı bilgi, tüm sistemlerin en önemli girdisi ve uygulanan faaliyetlerin sonucudur. Bilgi, organizasyon için girdi olmasının yanısıra, faaliyetleri yönlendirme ve faaliyetlerin sonucunda ortaya çıkan bir ürün özelliği de taşımaktadır. Buradan da anlaşılacağı gibi bir sistem bilgisiz devamlıığını sürdüremez (Paksoy, 1996, s. 56).

Bilgi, yöneticilere karar sürecindeki belirsizliğin azaltılması, düzeltici ya da uyarıcı eylemlerde bulunulması için geri bildirim sağlanması, hedeflerin oluşturulması, değerlendirilmesi, plan ve standartların geliştirilmesi ve eyleme geçirilmesi, gerçekleşen faaliyetleri ölçme ve faaliyet sonuçlarının standartlarından sapması halinde gerekli düzeltmelerin yapılması ve elde edilen başarıları değerlendirmesi için gereksinim duyulan tüm verileri içermesi durumlarında destek sağlamalıdır (Çimen ve Ateş, 2002, s. 2; Martin ve Powell, 1992, s. 19).

Amaç ve hedefleri farklı olsa da her organizasyon, yönetim fonksiyonlarını ve görevlerini yerine getirmek zorundadır. Bunun için her kademedeki yöneticinin zaman, mekan veya konuya göre değişen bilgi gereksinimlerini giderme zorunluluğu ortaya çıkmaktadır. Yönetim kademelerinde yetki ve sorumluluk sahibi kişiler, karar verme sürecinde öncelikle var olan bilgiyi kullanırlar. Bilgi merkezleri de kendi bünyelerinde bilimsel yönetimi oluşturmak, varlıklarını sürdürmek ve gelişim göstermek için belirlenmiş amaçlarını yerine getirmek, kullanıcılarının gereksinimlerini karşılayacak mal/hizmet üretmek, hedeflerine ulaşmak, üretim için gerekli olan mal/hizmetleri sağlamak ve yönetim işlevlerini yerine getiren bağımsız bir yönetim birimine sahip olmalıdır (Yontar, 1995, ss. 87-89). Bilgi merkezinin bünyesinde bulunan yönetim birimi, sözü edilen işlevleri yerine getirebilmek, belirlediği hedef ve amaçlara yönelebilmek, örgütün geleceğine ilişkin etkili kararlar alabilmek; planlama, örgütlenme, yöneltme, koordinasyon, karar verme ve denetleme gibi yönetim fonksiyonlarının sağlıkı işlemesi için iç ve dış kaynaklardan gerekli bilgiyi toplamak ve kullanmak durumundadır.

Bilgi merkezleri diğer organizasyonlar gibi iç ve dış çevreye sahiptir. Ekonomik koşullar, mali kaynakların durumu, demografik koşullar, teknoloji, tarihsel gelişim, kullanıcılar, hedef gruplar, insan kaynakları, kaynaklar ve 
diğer materyaller, siyasi durum, sosyo-kültürel durum, mevzuat ve hükümet, bilgi merkezinin diş çevresini oluşturur (Bryson, 1990, s. 24; Çelik, 1994, s. 50). Bir bilgi merkezi için bu koşullar arasında öncelikte göz önüne alınması gerekenler, bilgi kaynakları (derme-koleksiyon), insan kaynakları, nüfus, sosyo-kültürel yapı ve mevzuattır. Bir organizasyonun iç çevresini ise, personel, bütçe, bina, mali kaynaklar ve ürün/hizmetler oluşturmaktadır.

Bilgi merkezinin yönetimi için gereken bilgi yukarıda adı geçen iç ve dış çevreden elde edilmekte ve kullanılmaktadır. Ancak farklı tür bilgi merkezlerindeki ve bunların çeşitli bölümlerindeki yönetici ve çalışanlar değişik sorumluluklar ve yeteneklere sahiptirler. Bu nedene bağlı olarak farklı bilgi ve teknolojiye gereksinim duyarlar. Sözü edilen farklı bilgi gereksinimleri Tablo 1 'de gösterilmektedir.

Tablo 1. Bilgi Merkezlerinde Yöneticilerin Bilgi Gereksinimi (Anameriç, 2003, s. 192).

\begin{tabular}{l|l} 
Yönetici (Sorumlu) Türü & Gereksinim Duyulan Bilgi Türü \\
\hline Üst Kademe Yönetici(ler) & $\begin{array}{l}\text { Personel bilgisi, yönetim bilgisi, mali } \\
\text { bilgi, kullanıcı bilgisi, materyal } \\
\text { bilgisi, mevzuat bilgisi }\end{array}$ \\
\hline Seçim ve Sağlama Böl. Sorumlusu & $\begin{array}{l}\text { Mali bilgi, ekonomi bilgisi, materyal } \\
\text { bilgisi, mevzuat bilgisi }\end{array}$ \\
\hline Kataloglama ve Sınıflama Böl. & $\begin{array}{l}\text { Kataloglama ve sınıflama kuralları, } \\
\text { materyal bilgisi, bilgisayar bilgisi, } \\
\text { enformasyon teknolojisi bilgisi, } \\
\text { otomasyon, materyal bilgisi, } \\
\text { mevzuat bilgisi }\end{array}$ \\
\hline Süreli Yayınlar Böl. Sorumlusu & $\begin{array}{l}\text { Materyal bilgisi, kullanıcı bilgisi, } \\
\text { mali bilgi, muhasebe bilgisi, } \\
\text { mevzuat bilgisi }\end{array}$ \\
\hline Danışma Böl. Sorumlusu & $\begin{array}{l}\text { Kullanıcı bilgisi, materyal bilgisi, } \\
\text { psikoloji bilgisi, tanıtım-reklam bilgisi, } \\
\text { halkla ilişkiler bilgisi, mevzuat bilgisi }\end{array}$ \\
\hline Kullanıcı Hizmetleri Böl. Sorumlusu & $\begin{array}{l}\text { Materyal bilgisi, sosyoloji bilgisi, } \\
\text { kullanıcı bilgisi, mevzuat bilgisi }\end{array}$ \\
\hline
\end{tabular}

Bilgi merkezi yöneticileri, bilgi merkezinin gerçekleştirmiş olduğu işlem ve hizmetler, personelin performansı, kullanıcı tatmini, verilen hizmetin kalitesi ve bütçe ile ilgili olarak alt bölümlerden gerekli yönetim bilgisini edinmek 
durumundadır. Bunun dışında alınacak kaynakların fiyatları, döviz kurları, bilgi merkezinin hizmet politikası ve kullanıcı isteklerine göre yeni çıkan kaynaklar ile ilgili olan bilgilere de gereksinim duyarlar.

Bilgi merkezleri günlük işlemler sonucunda çeşitli özelliklerde veri ve bilgi üretmektedirler. Üretilen veri ve bilgiler, kuruma hem kaynaklık eder hem de yöneticilerin özellikle planlama, karar verme ve denetleme işlemlerini kolaylaştırmasına yardımcı olur. Bu kurumların günlük işlemleri sonucunda elde ettikleri veriler, sunulan hizmetler, ortaya konulan performans ve gelecekte içinde bulunulabilecek durumlar konusunda yöneticilerin fikir sahibi olmalarının yanısıra planlanmalarında daha gerçekçi bir biçimde yapılmasını sağlar. Sözü edilen işlemler için bilgi merkezlerinde üretilen ve gerektiğinde kurum dışından elde edilen bilginin istenilen biçimde, zamanda ve yerde yöneticilere ulaştırılmalıdır. Bu işlem için bilgi merkezlerinde yöneticilerin gereksinim duyduğu bilgiyi en kısa sürede, en verimli ve anlaşıı biçimde ulaştıracak bilgi sistemlerinin kullanılması gerekmektedir.

\section{Bilgi Sistemleri ve Bilgi Merkezlerinde Kullanılabilecek Bilgi Sistemleri}

Bilgi sistemleri; organizasyonlarda bilgi toplama, işleme ve dağıtma işlemlerini yerine getiren insan kaynakları, bilgisayarlar ve yöntemler dizisidir. Bilgi sistemi, bilgisayarlar ve iletişim araçları (bilişim teknolojileri) yardımıyla, yöneticilerin iç ve dış çevrelerindeki olaylardan, fırsatlardan ve beklenmedik durumlardan haberdar olmalarında büyük kolaylıklar sağlamaktadır.

Bilgi sistemlerinde, gereksinim duyulan bilginin sağlanması girdi, işlem ve çıktı olmak üzere üç temel aşamada gerçekleşir (Gökçen, 2002, ss. 36-38). Girdi, verinin organizasyon içinden ve dışından sağlanması; işlem, toplanan verinin anlaşıı bir duruma getirilmesi için geçen süreç; çıktı ise, işlem sürecinde elde edilen bilginin gereksinim duyan kişilere çeşitli formlarda dağıtılmasıdır. Bunun yanında, bilgi sistemi, sistemin tekrar çalışabilmesini sağlamak, kullanıcılardan gelen istek ve yeni gereksinimleri değerlendirmek için bir geribildirim özelliğine de sahiptir.

Bilgi sistemleri, hem çeşitli kademelerdeki yöneticiler hem de çalışanlar için gereklidir. Bu nedenle yönetim ve yöneticilere sağladığı olanaklar, organizasyonun iç ve dış çevresi, hizmet politikası, bilgi gereksinimleri gibi değişkenlere göre şekillenmektedir. Bilgi sistemleri yöneticilerin, organizasyon çevresindeki benzer organizasyonlar, müşteriler ve devlet kurumları ile ilişki kurmasında yardımcı olur.

Bir sistem olarak bilgi merkezi, kendisini meydana getiren bir takım alt sistemlerden oluşmaktadır. Bilgi merkezleri - kütüphaneler beş temel unsurdan meydana gelmektedirler. Bunlar; bina ve diğer fiziksel kaynaklar, kullanıcılar, 
mali kaynaklar, personel ve dermedir (Yontar, 1995, s. xii, Çelik, 2001, s. 3). Bilgi merkezi üst sistemini meydana getiren bu beş temel bileşenin iyi işleyebilmesi için öncelikle, bibliyografik denetimin sağlanması, bilgi - iletişim teknolojilerinin ve bilgi sistemlerinin kullanılması gerekmektedir. Kütüphaneleri meydana getiren bileşenler aynı zamanda, kütüphanenin iç bilgi kaynaklarını ve kütüphane sisteminin alt istemlerini de oluşturmaktadır.

1970'li yılların başından itibaren bilgisayarların kütüphanelerde - özellikle halk ve araştırma kütüphanelerinde - kullanılması, yönetim için gerekli olan bilgilerin bilgisayarlar yardımıyla işlenip dağıtılabileceği fikrini geliştirmiştir. Bu nedenle bilgisayarların da yardımıyla, bilgi merkezlerinde yönetim bilgi sistemlerinin oluşturulması ön plana çıkmıştır. Bilgisayar tabanlı bilgi sistemleri özellikle yönetim bilgi sistemleri, kütüphanecilik ve enformasyon bilimleri literatüründe uzun zamandır tartışılan, ancak daha çok ticaret ve endüstri alanlarında yaygın olarak kabul gören bir kavramdır (Ferguson ve Whitelaw, 1992, s. 184). Bilgi-iletişim teknolojilerinin çeşitli türdeki organizasyonlarda farklı işlemler için kullanımının artması, organizasyon yönetiminin karmaşıklaşması ve sistem yaklaşımı görüşünün yaygınlaşması, bilgi tabanlı birer işletme olan bilgi merkezlerinin yönetimlerinde de bir takım yeniliklerin kabul edilmesini sağlamıştır. Bu yenilikler, bilgi merkezi faaliyetlerinin otomasyona geçirilmesi, geliştirilmesi ve kurumun daha etkin ve verimli olarak yönetilmesi şeklinde özetlenebilir. Bilgi merkezi faaliyetlerinin otomasyona geçirilmesi ve hizmetlerin geliştirilmesi, çeşitli otomasyon programları ve bunları bütünleyen araçlarla gerçekleştirilebilir. Ancak, bilgi merkezlerinin etkin ve verimli biçimde yönetilmesi için özellikle planlama, yürütme ve denetleme fonksiyonlarının iyi işlemesi gereklidir. Bu fonksiyonların iyi işlemesi ise, tüm kütüphane türlerini meydana getiren unsurlarla ilgili verilerin toplanarak kullanıır hale getirilmesi ile olanaklı kılınır.

Bilgi merkezi yöneticileri, stratejik planlamalarını daha kolay, hızlı ve verimli bir biçimde yapabilmeleri, dikkatli bir planlama stratejisi, bilgisayar bilgisi ve uygun bir yazılım ile geliştirdikleri sisteme bağlıdır (McClure, HagertyRoach ve Lindsay 1989, s. 192). Bu sistem, doğrudan bilgi merkezlerine çeşitli yönetim kademelerinde (alt, orta ve üst kademe) bulunan yöneticilere yönelik olarak düzenlenmelidir.

Bilgi merkezlerinin çevresi de diğer organizasyonlarda olduğu gibi hızlı bir değişim içerisindedir. Birçok iç ve dış etken bilgi merkezini çeşitli yönlerden etkilemektedir. Bu etkiler ışığında bilgi merkezleri ve bu kurumların yönetici ve çalışanları bazı temel sorulara yanıt vermek durumundadırlar. Bu sorular; Biz ne yapmalıyız? Kullanıcımız kimdir? Performansımız nasıl? Şu anda yaptığımızdan daha iyisini yapabilir miyiz? (Lakos, 1997). Birçok bilgi merkezi, bu temel soruları daha iyi yanıtlayabilmek için işlemlerini yeniden 
tanımlamakta, yapılarını değiştirmektedir. Bu değişiklik ve tanımlamaların yapılmasındaki neden, işlemlerin daha etkili ve verimli olarak gerçekleştirilebilme isteğidir. Olumlu sonuçların elde edilmesi için bilgi merkezleri, bilgiyi daha iyi bir biçimde kullanmak zorundadır. Bilginin iyi kullanılması için doğru, anlamlı ve zamanında toplanması gerekir. Bilginin bu biçimde toplanması ve gereken yerlere iletilmesi için günümüzde bilgi teknolojileri ve bilgi sistemlerinden yararlanılmaktadır. Bilgi sistem ve teknolojilerinin bilgi merkezleri ve yönetim kademelerinde kullanımı Tablo-2'den izlenebilir.

Tablo 2. Bilgi Teknolojilerinin Bilgi Merkezlerinde Kullanım Alanları (Ward, 1995, s. 3).

\begin{tabular}{l|l|l|l|l}
$\begin{array}{l}\text { Bilgi Teknolojisi } \\
\text { Uygulamaları }\end{array}$ & $\begin{array}{l}\text { Stratejik } \\
\text { Planlama }\end{array}$ & $\begin{array}{l}\text { Taktiksel } \\
\text { Planlama }\end{array}$ & $\begin{array}{l}\text { Operasyonel } \\
\text { Planlama }\end{array}$ & $\begin{array}{l}\text { Değişim } \\
\text { ve Yenilik }\end{array}$ \\
\hline $\begin{array}{l}\text { Günlük ve Geçmişe } \\
\text { Yönelik Bilgi }\end{array}$ & $*$ & $*$ & $*$ & $*$ \\
\hline Araştırma Teknikleri & & $*$ & $*$ & \\
\hline $\begin{array}{l}\text { Planlama ve } \\
\text { Simulasyon }\end{array}$ & $*$ & $*$ & & $*$ \\
\hline $\begin{array}{l}\text { Bilgi Tabanlı Yöntemler } \\
\text { (Sayısal veri } \\
\text { kullanmayan) }\end{array}$ & & $*$ & $*$ & $*$
\end{tabular}

Bir bilgi merkezinde üç farklı bilgi sistemi bulunabilir. Bunlar; veri işleme sistemleri, yönetim bilgi sistemleri ve karar destek sistemleridir. Bu sistemler birbirleriyle ilişkili olarak bir arada veya tek tek kullanılabilir. Bilgi sistemleri, yöneticilerin karar almada kullanacakları veri ve/veya bilginin düzenli ve sürekli biçimde toplanmasını, işlenmesini, saklanmasını, yorumlanmasını ve aktarılmasını sağlamaktadır. Bu yüzden hemen hemen her yöneticinin bir bilgi sistemi olmalıdır.

\section{Veri İşleme Sistemleri (Vis)}

Veri işleme sistemleri, organizasyonlardaki günlük işlemler sırasında meydana gelen verilerin ve elde edilen kayıtların toplanması, işlenmesi ve çeşitli kademelerdeki yöneticilerin kullanımına hazır duruma getirilmesi için geliştirilmiştir. İlk oluşturulan bilgi sistemi olan Vis; bir alındı kaydı ve bu kaydın 
makbuz oluşturulma işi için kullanılmıştır (Gökçen, 2002, s. 41; Lucey, 1987, s. 9). Bu sistemde, geçmiş ve çok yakın gelecekteki verilerin değerlendirilmesi ile günlük işlerde etkinlik sağlanmaya çalışılmıştır. Organizasyonla ilgili maaş, sigorta, vergi, çek, tahsilat ve stok işlemleri ile ilgili kayıtları içeren ViS'in temel amacı, daha önce elci (manuel) olarak yapılan, uzun zaman ve emek gerektiren hesaplamaların otomatik olarak makineler yardımıyla daha kısa sürede, doğru ve en az maliyetle yapılmasını sağlamaktır. ViS'in başlıca kullanıcıları; çeşitli görevlerdeki büro elemanları ve genelde şef düzeyindeki yönetici kademeleridir (Bensghir, 1996, ss. 55-56). Veri işleme sistemleri, bir organizasyonda kuralları belirli, yapısal olarak izlenebilir, tanımlanabilir, kabul görmüş, modellenebilir süreçlerin çalıştııımasında ve bu tür problemlerin, kısaca rutin büro işlemlerinin makineleştirilmesinde kullanılır (Anameriç, 2005, 123; Öztemel, 1998, s. 1175). Veri işleme süreci temel olarak üç ana bölümden oluşmaktadır. Bunlar;

$>$ Günlük faaliyetlerin işlenmesi,

$>$ Rapor işleme,

> Sorgulamaların işlenmesidir (Lucey, 1987, s. 185).

Günlük faaliyetlerin işlenmesinde, siparişler, alındılar, ödemeler, makbuzlar, faturalar, sipariş kayıtları, materyal istek fişleri gibi işlemler sayılabilir. Rapor işleme, belirlenmiş aralıklara göre hazırlanan satın alma, ödünç verme, personel faaliyetleri gibi işlemleri kapsar, sorgulamalar ise, stok kontrol, tarama sonuçları gibi işlemlerdir. ViS'de, önceden belirlenmiş bilgi, yine önceden belirlenmiş kurallar (prosedürler) çerçevesinde uygun standartlarda üretilir ve bilgi merkezlerinin ilgili birimlerine gönderilir (Ferguson ve Whitelaw, 1992, s. 185). Örneğin; daha önceden saptanan bir zaman aralığı içerisinde, ödünç verilmiş kaynaklara ilişkin bilginin standart raporlar ve istatistiksel değerlendirmeler halinde, ödünç verme bölümünden sorumlu yöneticiye ulaştırılması, bu tür bir veri işleme işlemidir.

vis, organizasyonlarda verilerin daha hızlı işlenmesi ve iletilmesinin yanısıra hataların azaltılması, saklanan veri ve bilginin güvenliğinin sağlanması, terminaller aracılığıyla veri ve bilgiye ulaşılması, doğruluk ve güvenilirlik oranının artıııması, işıemlerin yapıldığı anda kayıtlara geçirilmesi ve analizlerin gerçekleştirilmesinde önemli avantajlar sağlamaktadır. Bu bağlamda Vis, özetle şu niteliklere sahiptir; bu sistemler işlemleri yürütme ve kayıt tutma üzerinde yoğunlaşır, çıktıları belirli aralıklara göre belirlenmiştir, organizasyonların eylemsel planlama kademesindeki çalışanlara ve yöneticilere bilgi sağlarlar. Ancak sonucu bilinen rutin hesap işlemlerini yerine getirmesi ve farklı bilgi gereksinimlerini karşılama yeteneğinin olmaması nedeniyle bu sistemlerin karar alma işlemleri üzerinde etkisi azdır. 


\section{Yönetim Bilgi Sistemleri (YBS)}

Yönetim bilgi sistemi, kâr amacı güden ve/veya gütmeyen organizasyonlara uygulanabilen ve temel olarak farklı yönetim kademelerindeki yöneticilere; gereksinim duydukları bilgiyi sağlar. Bir örgütte yönetim ve karar alma işlemlerine destek olmak amacıyla enformasyon sağlayan bütünleşik, insan makine etkileşimli bir sistem olarak, istenen bilgiyi sağlamak için bilgisayar yazılım ve donanımı, yöntemleri (prosedür), analiz, planlama, denetleme ve karar alma modellerini ve veri tabanını kullanır (Davis, 1985, s. 6).

YBS'nin organizasyonlara uygulanması sadece 30-35 sene öncesine dayanmasına ve teknolojik gelişmelerin devam etmesine karşın, YBS organizasyonların beyni olma görevini sürdürmektedir. Gelişen teknoloji, YBS'ye destek sağlamakta ve güncellemektedir. YBS, bilginin en üst seviyede elde edilerek işlenmesini, depolanmasını, gerekli yerlere iletilmesini sağlayarak, bilgiden en üst düzeyde yararlanılmasını olanak kılan en önemli araçtır.

YBS, daha çok endüstri ve işletme alanlarında kullanılmakta olan bir kavramdır ve bilgisayar, yönetim ve muhasebe alanları ile yakın ilişki içerisindedir. Bu özelliği ile YBS, tekil bir sistem olmaktan çok geniş bir sistemdir. Günümüzde bilgisayarların her türlü organizasyonda etkin olarak kullanılması nedeniyle YBS'nin uygulama alanı genişlemiş̧tir (Davis, 1985, s. 32; Cullen, 1992, s. 152). Modern yönetim bilgi sisteminin oluşmasında temel olarak üç alanda yaşanan gelişmelerin önemli katkıları olmuştur. Bunların başında bilgisayar ve iletişim araçlarının, diğerleri ise, muhasebe sistemi ve yönetim teorilerinin geliştirilmesidir. 1970'lerde boyutları küçülmüş, işlem hızları ve veri depolama hacimleri büyümüş bilgisayarların üretilmesi, YBS'nin gelişmesini hızlandırmıştır (Lucey, 1987, s. 297).

Bir YBS'nin birincil görevi karar almak için gerekli formda üretilmiş olan veriyi ya da bilgiyi sağlamaktır. Şu an kullanılmakta olan YBS'ler, farklı türdeki işlemlerin ayrıntılarını içeren raporlar oluşturarak, sözü edilen bilgiyi yönetim kademelerine sunmaktadır. Raporların türleri ve hazırlanış süreleri çeşitli şekillerde düzenlenebilir. Yönetim bilgi sistemi tarafından hazırlanan bilgi, özetlenmiş, tablolara dönüştürülmüş veya daha kullanışlı bir formda üretilmiş ve bilgi merkezi yöneticileri tarafından erişilebilir biçimde olmalıdır. YBS'nin temelinde yatan enformasyon olgusu tüm yönleri ile bilgi merkezlerinin çalışma alanlarını kapsamaktadır (Karakaş, 1991, s. 254).

YBS, bilgi sistemini meydana getiren unsurlar, bilgi merkezinin işlemlerini birbirine bağlayan harç gibidir. Bu sistem, problemlerin çözümlenmesinden, karar modellerinin uygulanmasına kadar, bir kütüphanenin günlük işlemleri için gereken verileri, aynı zamanda, bilgi merkezinin faaliyetleri ve görevleri, gerçek ve potansiyel kullanıcıları, bilgi merkezi-kullanıcı ilişkisi ve diğer ilgili etkenler hakkındaki bilgileri sağlar. YBS, bilgi merkezi içi ve dışından dört 
temel kaynak yardımıyla bilgi toplamaktadır. Bunlar; bilgi merkezlerinin hizmet verdiği gerçek ve/veya potansiyel kullanıcılar ve çalışan personel arasındaki ilişkiler (ödünç verme, danışma, sorgulama vb.), bunların dışında kalan kişi ve kurumlar (diğer bilgi merkezleri, yayıncılar, aracı firmalar, bürokratlar vb.) dır (Brophy, 1986, s. 85).

YBS'de, önceden düzenlenmiş ve belirlenmiş bilgi, sistemi daha iyi yönetmek ve denetlemek amacıyla, yöneticilere standart raporlar aracılığıyla iletilir. Örneğin; bilgi merkezinin geçen yıla ait ödünç verme istatistikleri ile içinde bulunulan döneme ait ödünç verme istatistiklerini karşılaştırarak, performans değerlendirmesi ve hedeflere ulaşmada kullanılacak doğru verilerin yorumlanarak raporlar halinde yöneticilere iletilmesi işlemleri, YBS'nin görevidir.

Tüm bilgi merkezlerinde, resmi olmasa da, adına yönetim bilgi sistemi denilmese de bilgi sağlayan bir sistem vardır. Bilgi merkezi çalışanlarının kişisel olarak hazırladıkları raporlar, bölümler ve kişilerarası yapılan resmi ve gayri resmi görüşmeler, fatura ödemeleri, hesaplamalar, notlar belirli bir standarda sahip olmayan ancak kullanılmakta olan bir bilgi sistemini ifade etmektedir (Anameriç, 2003, s. 222). Bu açıdan bakıldığında YBS, bu standartlaşmamış ve kurallar ile belirlenmemiş bilgi kaynaklarını, öncelikle standart hale getirerek, tek bir veri tabanında veya birbiriyle ilişkili birden fazla veri tabanında toplar. Veri tabanları, tek başlarına hiçbir anlam ifade etmeyen verileri ilişkilendirerek yorumlar, verileri türlerine ve boyutlarına göre sınıflandırır. Sınıflandırılan veriler, ilerleyen zamanlarda karşılaşılan farklı durumlarda kullanılmak üzere depolanır ve son olarak gereksinim duyulan anda yöneticilerin stratejik kararlarını alabilmesi için özet olarak doğru bir biçimde iletilir.

YBS ile ViS arasındaki farklılıklar şu şekilde belirtilebilir; ViS, organizasyonlarda yalnızca bir işlevi desteklemesine karşın, YBS hemen tüm işlemlerle ilgilidir ve bunlar arasındaki bilgi iletimini yerine getirir. Vis genel olarak eylemsel düzeydeki işlemleri, YBS ise tüm kademelerdeki işlemleri desteklemektedir. YBS, yarı yapısal nitelikteki kararlara etkili destek verirken, yapısal olmayan ve programlanamayan nitelikteki sorunların çözümünde alınacak kararlara gereken desteği sağlamaz. Bu türlü sorunların çözümünde gerek Vis, gerekse YBS temeline dayalı olarak geliştirilen karar destek sistemleri devreye girmektedir (Bensghir, 1996, s. 84; Anameriç, 2005, ss. 167-169).

\section{Karar Destek Sistemleri (KDS)}

Karar destek sistemi, herhangi bir bireyin, bir eylemin kesin olarak nasıl yapılacağının bilinmediği durumlarda kişilerin karar almasını ve kendi muhakeme yeteneklerini kullanmasını destekleyen ve yardımcı olan etkileşimli bir sistemdir (Alter, 1997, s. 133). Çoğunlukla üst kademe yöneticiler tarafından kullanılan KDS, genellikle yapılanmamış ya da yarı 
yapılanmış durumlarda yöneticilere destek sağlar. Örgütlerde temeli yönetsel faaliyetlere dayanan üç farklı tür karar tipi vardır. Bunlar; yapılanmış (structured), yarı yapılandırılmış (semi-structured) ve yapılanmamış (unstructured) kararlardır (Lucas, 1986, s. 421).

Yapılanmış kararlar; ortaya çıkan sorunun yapısına göre belirli yöntem veya kurallar doğrultusunda alınır. Bu tür kararlar; organizasyonun belirlenmiş olan planları, politikaları, stratejileri, bütçeleri ve yöntemlerine uygun şekilde ve daha önceden karşılaşılan durumlar sonucu elde edilen deneyimlerden oluşmaktadır. Yarı yapılanmış kararlar karşılaşılan sorunun bazı yönlerine belirli bir karar süreci veya yöntemi uygulanabilen türlerdir ve yöneticinin kendi insiyatifini kullanması ve karar vermesi gerekmektedir. Yapılanmamış kararlar ise, karar almaya etki eden birçok rastlantısal durum nedeniyle belirli bir süreç ve yöntem uygulanarak çözümlenemeyen olgular için alınır. Bunlar organizasyonun belirlenmiş olan planları, politikaları, stratejileri, bütçeleri ve yöntemlerine uygun olmayan kararlardır. Yapılanmamış kararlarda organizasyon genel olarak hazırlıksızdır, çünkü bu kararı gerektirecek durumla karşılaşmamış veya bu durumla ilgili yeterli bilgiyi edinmemiştir. Yapılanmamış kararlar, üst kademe yöneticiler tarafından stratejik planlama için kullanılmaktadır (Himmetoğlu, 1971, s. 11).

KDS diğer geleneksel bilgi sistemlerinden farklı bir yapıya sahiptir. Bu sistemleri diğerlerinden ayıran en önemli unsur, tamamıyla yöneticilerin yetki alanları içinde olmasıdır. KDS, yöneticiler için oluşturulmuş ve onlar tarafından kullanılmasının yanısıra, organizasyonların yönetim bilgi sistemlerinin de bir parçasını meydana getirmektedir. Bir KDS, kurumsal ya da yönetsel işler için kurulan bir bilgi sistemine uygulanan yaklaşımlardan biridir, aslında karar destek sistemi tipik olarak özel bir yönetsel işe veya özel bir probleme uyarlanmıştır ve onun kullanımı bu problemin çözümü ve işin sonuçlandırılması ile sınırlanmıştır (Davis, 1985, s. 11). Bu sistemler, organizasyonun tüm kademelerindeki yöneticilere hizmet verme amacıyla oluşturulmalarına karşın, öncelikli olarak orta ve üst kademe yöneticilere hitap etmektedir.

KDS'yi diğer iki bilgi sistemlerinden ayıran özellikler şunlardır:

> Yapılan günlük işlerin değerlendirilmesinden çok karar verme sürecine destek odaklıdır.

> Olay bir biçimde düzenlenir; yapısı, uygulanması ve değiştirilmesi basittir.

$>$ Sadece yöneticilerin kullanımı için tasarlanmıştır.

$>$ Bir soruyu yanıtlamaktan çok yönetsel analizde kullanılacak olan enformasyonu sağlar. 
> Yalnızca küçük bir analiz alanı veya büyük bir problemin küçük bir bölümü ile ilgili olmalarından çok, büyük bir problem ya da işlem için kullanilırlar.

$>$ Daha önce karşılaşılmış durumlarda yöneticilere karar önerileri sunabilen bir mantığa sahiptir.

$>$ Organizasyonun içinden ve çevresinden gelen bilgiyi depolayan bir veri tabanına sahiptir.

$>$ Yöneticilerin alternatif kararlarının muhtemel sonuçlarını test etmelerine olanak tanır (Scott, 1986, s. 81).

KDS, karar almada, insan makine etkileşiminde denetimin insanın elinde olmasını sağlar. Yapılanmış, yarı-yapılanmış ve yapılanmamış problemlere çözüm bularak karar vermeye yardımcı olan, soruna uygun matematiksel veya istatistiksel modellerin kullanımını sağlayan, her düzeydeki organizasyon yöneticisi için kapsamlı veri tabanı sağlar. Sistem karar alma ve kontrol işleminde işlemlerin makineleşmesinden çok, bu işlemlerin etkili bir biçimde yürütülmesini kolaylaştırır, geleceğe yönelik kararların alınmasına göre planlanması sayesinde geçmişte yaşanan problemlerin çözümlerini yeni durumla karşılaştırarak çözüm yolları üretir. Bunların dışında yeni durumlara açık ve esnek bir yapıya sahiptir.

\section{Bilgi Sistemlerinin Bilgi Merkezleri İçin Önemi}

Bilgi merkezleri, bilginin depolandığı ve bilgiye erişimin sağlandığı sosyal kurumlardır. Bu kurumlar; personel, derme, bütçe gibi olanaklarıyla hedefledikleri kullanıcı gruplarına gereksinim duydukları bilgiyi en kısa sürede ve hızlı bir biçimde iletmeyi amaçlamaktadır. Bilginin en kısa sürede ve hızı bir biçimde iletilmesi için bilgi merkezinin iyi yönetilmesi gerekmektedir. Yönetimin görevi ise, sistemin temel amacının gerçekleştirilmesi için tüm sistemi oluşturan birimlerin işlevlerini yerine getirebileceği, uygun ortamı sağlamak ve sistemi sürekli denetlemektir. Organizasyon hakkında ne kadar çok şey bilinirse, o kadar kolay ve verimli yönetilir. Bilgi merkezi yönetiminin gereksinim duyduğu bu bilgilerin bir sistem içerisinde ve düzenli olarak çeşitli yönetim kademelerindeki yöneticilere ulaştırılmasının ve bölümlerarası bilgi akışını sağlanmasının en verimli ve hızlı yolu bir bilgi sisteminin oluşturulmasıdır (Anameriç, 2003, s. 350).

Bilgi sistemleri, diğer organizasyonlarda olduğu gibi bilgi merkezlerinde de günlük, rutin işlemlerin daha kısa sürede, daha az emek ve para harcanarak yapılması amacıyla kullanılmıştır. Bilgi sistemlerinin, bilgi merkezlerinde kullanımına bakıldığında; bu sistemlerin tarihsel gelişimi ile paralel olduğu görülmektedir. İlk olarak Vis, özellikle muhasebe, maaş, sigorta vb. işlemlerin 
daha kısa sürede ve daha güvenilir bir biçimde sürdürülmesi için, organizasyonun tüm kademelerdeki yöneticilere karar alma sürecinde bilgi desteği sağlayan YBS kullanılmaya başlamıştır. Yönetim bilgi sistemlerinden daha sonra KDS bilgi merkezlerinde karar verme ve planlama yapma amacıyla kullanılmaya başlamıştır. Bu sistemler, gelişim süreci içerisinde birbirlerinin eksiklerini de kapatmıştır.

YBS, bilgi merkezlerinin daha etkili ve verimli bir biçimde yönetilmesi daha sağlam kararların verilebilmesi ve yöneticilerin zamanında ve doğru bilgiye olan gereksinimlerini karşılamak amacıyla kullanılmaktadır. Bilgi merkezlerinin etkili ve verimli yönetilmesi için kendi iç ve dış çevresi ile ilgili yönetim bilgisinin elde edilmesi, yorumlanarak kararlara dönüştürülmesi ve iyi kavranması gerekmektedir. Yönetim bilgisi, tüm bilgi merkezi organizasyonunu kapsayan bir yapıya sahiptir ve yönetim için vazgeçilmez bir kaynaktır. Günümüzde bilgi merkezlerinde uygulanan çağdaş yönetim yaklaşımında, bilgi merkezlerinin tüm işlemler ve hizmetlerinde, hem bu işlem ve hizmetlere ilişkin bilimsel mesleki bilgiden, hem de yönetim sürecindeki işlemler için gerekli olan bilimsel bilgiden yararlanma söz konusudur. Bu tür bilgilerin yönetim kademelerine ulaştırılması için yapılan işlemlerin bütünü ise, yönetim bilgi sistemlerinin bilgi sağlama işlemleri kapsamında yer almaktadır (Anameriç, 2003, s. 351 ve Lucey, 1987, ss. 217-219).

Bilgi merkezleri uzun süredir, insanların bilgi gereksinimlerinin karşılandığı ve bilginin depolandığı mekanlar olarak varlıklarını sürdürmektedir. Bu merkezler, teknoloji ve yönetim anlayışının gelişmesi ile birlikte geçmişteki durumları ile karşılaşı̧ııldığında birçok açıdan farklı durumdadırlar. Bilgi merkezleri halen bilginin en büyük depolayıcıları ve düzenleyicileri olmalarına karşın, var olma nedenleri değişmiş, derme oluşturmadan bilgiye erişime kadar gözle görülür geniş bir çevreye yayılmıştır (Fulweiler ve Dugan, 2001, s. 386). Bilgi merkezi içi ve dışında meydana gelen bu değişimlerden yönetim ne kadar çabuk ve doğru biçimde bilgi edinilebilir ise, geleceğe yönelik stratejik kararlar da o kadar çabuk ve doğru biçimde alınır.

Bilgi merkezlerinin iyi bir biçimde yönetilebilmeleri için, bilgi merkezini oluşturan parçaların ve onların sistem bütünü içerisindeki işlemlerinin açık bir biçimde tanımlanması gerekmektedir. Bilgi merkezlerinin yöneticileri, bilgi merkezinin amaçlarını, görevlerini, kaynaklarını, hedeflerini, alt sistemlerini ve kullanıcılarını iyi tanımalıdır. Yöneticilerin sözü edilen unsurları iyi tanıması, bunlarla ilgili bilgileri düzenli ve anlaşıı biçimde elde etmesiyle mümkündür. Böylelikle bilgi merkezi yönetiminin yapması gereken planlama, örgütlenme, yürütme, koordinasyon, karar verme ve denetleme işlemlerini desteklemek, bilgi merkezinin etkinliği, verimliliği ve performansının artırımasını sağlamak çok daha kolay ve yeterli olacaktır. 
Bilgi merkezlerinde bulunan yönetim bilgi sistemi, ilişkisel veri tabanları ve dış çevreye ait geniş bilgilere dayanan karmaşık ve güçlü bir sistemdir ve bu sistemin çalıştııılması için sistem hakkında bilgili uzman personele gereksinim vardır. Bilgi merkezleri mali işlemler, derme geliştirme, karar verme, plan hazırlama, tahminlerde bulunma, işlem ve hizmetlerin verimliğinin ölçülmesinde gerekli olan yönetim bilgisini sağlamak amacıyla, yönetim bilgi sistemlerini kullanılmaktadırlar. YBS, sağlayacağı yönetim bilgisi ile bilgi merkezinin yönetim sürecini daha verimli ve etkili bir yönetim aracına dönüştürmektedir (Anameriç, 2003, s. 354).

Farklı kullanıcılar ve bunların değişik bilgi gereksinimleri, çeşitli özelliklerde ve amaçlarda bilgi merkezlerinin oluşturulmasına neden olmuştur. Bu farklııklar bilgi merkezi işlem ve hizmetlerinin, dermesinin, bütçesinin ve personelinin de şekillenmesinde önemli rol oynamıştır. Bilgi merkezini oluşturan temel bileşenlerden kaynaklanan çeşitlilik, değişik kademedeki yöneticilerinin de gereksinim duyduğu bilginin farklılık göstermesini beraberinde getirmektedir. Bilgi gereksinimindeki farklılık ise; bilgi merkezleri için kullanılacak bilgi sistemlerinin kurulmasında ve uygulanmasında değişiklik gösterecektir. YBS'ler, doğrudan yöneticilere yönelik olmaları nedeniyle gereksinimler, amaç ve hedefler, yöneticilerinkiler ile paralel olacaktır. Sözü edilen unsurlar bilgi merkezlerinin hizmet politikaları, planları, uyması gereken mevzuat ve diğer kurallar yardımıyla şekillendirilir. Bu yapılanma, resmi ve gayri resmi düzeylerde kişilere özel olarak da düzenlenebilir. Örneğin; bir bilgi merkezi yöneticisinin kendi terminalinde (bilgisayarında), masaüstü objelerini sınıflandırması ve ilgilendiği konularla ilgili web sayfalarının adreslerini sık kullanılanlara eklemesinden, düzenli olarak sunulacak olan raporların ayrıntı düzeylerine kadar olan geniş bir alanda yönetim bilgi sistemleri uygulanabilir.

Hiyerarşik yapıya dayalı olarak yöneticiler, stratejik, taktiksel ve eylemsel düzeylerde bilgiye gereksinim duyacaktır. Üst düzey yönetimin konumu ve sorumlulukları gereği büyük ölçüde dış bilgi ile ilgilenmesi nedeniyle, bu kademede kullanılacak bilginin büyük çoğunluğu dış kaynaklardan elde edilmektedir. Dış kaynaklardan sağlanan ve üst düzey yöneticilerin kullanımına sunulan bilgi, bütçe artırımı, aracı firmalar, yeni teknolojik ve kanuni gelişmeler ile ilgili olabilir (Koory, 1987, s. 7; Lucey, 1987, ss. 211213). Bilgi merkezinin başkan, genel müdür veya daire başkanı gibi üst düzey yönetim kademeleri, bu açıdan ele alınırsa, daha çok kendilerinin bağlı bulundukları kurumlar, yeni kararlar, değiştirilen mevzuat, aracı firmalar, bütçe detayları gibi dış kaynaklı bilgilere gereksinim duymaktadırlar (Anameriç, 2003, s. 266). Bu bilgiler, bilgi merkezinin temel politikasını oluşturduğundan, üst düzey yöneticiler kadar diğer yöneticileri ve çalışanları da ilgilendirmektedir. 
Orta kademe yönetimi hem iç hem de dış bilgi ile ilgilenmektedir. Orta kademe yöneticilerinin kararları büyük oranda taktikseldir ve daha çok personel tahsisi, mali ve teknolojik kaynaklar, bilgi merkezi hizmetleri, çalışanların ve işlemlerin performansı ile ilgili raporlar ve bütçe raporları hakkındadır. Bu konularla ilgili veriler, organizasyon içinden ve diğer bilgi merkezleri ile ilgili dış kaynaklı bilgilerle birleştirilmiş biçimde elde edilir (Bryson, 1990, ss. 117-118; Lucey, 1987, s. 211).

Şekil 1. Yönetim Kademeleri ve Karar Verme (Anameriç, 2003, s. 267).

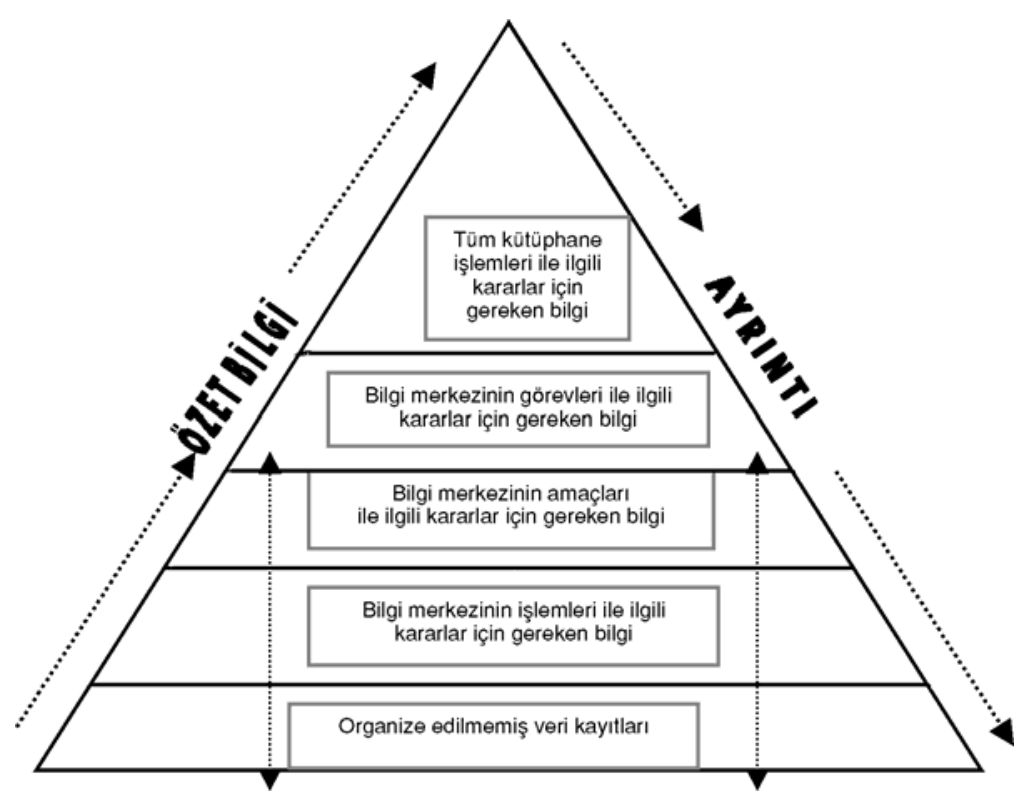

Bilgi merkezi yöneticileri; sağlama, süreli yayınlar ve ödünç verme bölümlerinden bütçe, harcamalar, dermeye eklenen kaynak, kalan bütçe, ek bütçe gerekliliği olup olmadığı gibi bilgileri; ödünç verme, elektronik kaynaklar, danışma hizmetleri, kataloglama ve sınıflama bölümlerinden, kullanılan derme sayısı, kayda geçilmiş derme sayısı, kullanım oranları gibi bilgileri elde ederler. Bu bilgiler sayesinde bilgi merkezinin stratejik planları belirlenerek, bu planların uygulanması için stratejik kararların alınması kolaylaştırılır. Yukarıdaki tabloda yönetim düzeyleri ve alacakları kararlar için gereken bilgiler görülmektedir. Şekil-1'de dikkat edilmesi gereken nokta, alt kademeden üst kademelere doğru giden bilginin özetlenmiş, üst kademelerden alt kademelere gelen bilginin ise ayrıntılı bir biçimde olmasıdır.

Yönetim kademeleri stratejik, taktiksel ve eylemsel olarak üç bölüme 
ayrılmıştır. En alt kademede faaliyetler sonucu ortaya çıkan ve henüz bir işlemden geçmemiş veri kayıtları yer almaktadır. Karar verme sorumlulukları, ise bu kademelere göre farklılık gösterir. Stratejik yönetim kademesindeki kararlar geleceğin planlanması, yeni hizmetlerin geliştirilmesi, iç ve dış verme odaklı kararlar, personel, derme, mali kaynaklar, teknoloji ve araç-gereç alımı, politika ve strateji geliştirme başlıkları altında toplanabilir. Taktiksel yönetim kademesindeki kararlar; kaynaklar ve bölümlerle ilgili işlemler, performans değerlendirmeleri, yeni hizmetlerin uygulanması, bütçe kaynakları ve derme geliştirme, eylemsel karar ise; personel alımı, ayrıntılı bütçe işlemleri, bütçe denetleme ve çalışanların denetlenmesi olarak belirlenebilir (Bryson, 1990, s. 118).

Alt düzey yöneticiler ise, gereksinim duydukları bilgiyi büyük oranda iç kaynaklardan sağlamaktadırlar. Alt düzey yönetim, emirleri orta kademe yönetiminden alır ve işlem kademesindeki etkinlikler ile ilgili verileri toplar. Bu kademedeki yöneticiler, toplanan veriler yardımıyla rutin günlük işlemlerle ilgili kararları destekler. Alt düzey yöneticiler, orta ve üst düzey yöneticilere göre çok daha ayrıntılı bilgiye gereksinim duyarlar, ancak işledikleri bilgiyi orta ve üst düzey yöneticilere özet bir biçimde iletmeleri gerekmektedir. Bu nedenle üretilen raporlar daha kısa, anlamlı ve özet bilgi verecek biçimde hazırlanmaktadır (Bryson, 1990, s. 119).

Veri işlem, yönetim bilgi ve karar destek sistemleri, bilgi merkezinin iç ve dış bilgi kaynaklarının verimli ve etkin bir biçimde kullanılmasına yardımcı olur. Çünkü, sözü edilen bu sistemler yönetim kademelerinin hızla değişen iç ve dış çevre koşullarına uyum sağlayarak, planlama yapmaya ve bu planlar doğrultusunda karar verme sürecine yardımcı olurlar. Veri işlem, yönetim bilgi ve karar destek sistemleri, organizasyonlarda stratejik amaçlar için kullanılan bilgisayar destekli sistemlerdir. Bu sistemler, iş alanının stratejik planlanmasını desteklemek amacıyla geliştirilmişlerdir (Bensghir, 1996, s. 51, s. 129).

Bilgi sistemleri, bu yararların yanısıra bilgi merkezlerindeki işlemlerin ve çalışanların değerlendirilmesi (performans değerlendirmesi) gibi bilgilerin elde edilmesine ve değerlendirilmesine de yardımcı olur. Bilgi merkezi faaliyetlerinin her aşamasında toplanan veri ve bilgiler, kütüphanenin hedefler ve performans ölçümü sırasında edinilen bilgiler, karar alma, planlama ve denetleme aşamalarında etkin bir biçimde kullanılmak amacıyla, birleştirilerek yorumlanır (Cullen, 1990, s. 27). Planlama ve karar verme süreçlerinde yöneticiye önemli destek sağlayan değerlendirme bilgileri, özellikle mali kaynakların etkin ve verimli biçimde kullanımını tasarlarken, bu kaynakların doğru biçimde yönlendirilmesine de olanak tanır. Bir gereksinimden dolayı yapılan performans değerlendirmesinde asıl olan, bir sorunun çözümlenmesi, bir belirsizliğin ortadan kaldıııması ve bir kararın verilebilmesi için uygun verilerin toplanmasıdır (Lancaster, 1988, s. 1; Alkan, 1996, s. 22). 
Performans değerlendirmesi için gereken veri ve bilgiyi, bilgi sistemleri sağlar. Değerlendirme, bilgi merkezlerinin önemli unsurlarından ve iç bilgi kaynaklarından birini oluşturmaktadır. Performans değerlendirme, hizmetlerin daha etkin ve verimli hale getirilebilmesi amacıyla faaliyetlerin ve çalışanların daha önceden hazırlanan göstergelere göre değerlendirilmesi işlemlerini kapsamaktadır. Değerlendirme, yönetimle özellikle de; planlama, karar verme ve denetleme faaliyetleri ile ilişkili bir süreçtir. Performans değerlendirmesinin temel amacı, işlemler ve kullanıcılar konusunda karar almayı kolaylaştırmaktır, bu nedenle, yönetim bilgi sistemleri için de hem kaynak, hem de yardımcı bir araç konumundadır. Sonuç olarak, performans değerlendirmesi sürecinde elde edilen bilgiler, hizmet ve faaliyetlerin etkililik ve verimliliğindeki gelişmeleri belgeleyerek işlemlerin geliştirilebileceği alanları önererek, açıklama, kanıt ve öneri seçenekleri sağlarken; bilgi merkezlerinin bu düzeylerdeki yönetici ve personelinin çalışmalarına yardımcı olur (Abbott, 1994, s. 2). Bu yönüyle ele alındığında performans ölçümü, yönetim bilgi sistemlerinin bir parçasıdır.

\section{Sonuç}

Stratejik planlama çalışmalarına yardımcı birer araç olan, veri işleme, yönetim bilgi ve karar destek sistemleri bilgi merkezi yönetimi açısından önemlidir. Bilgi merkezleri, amaçlarını belirlemeden önce planlama için bilgi gereksinimlerini ve bilgi merkezinin içinde bulunduğu durumu incelemelidirler. Ancak bu işlem zaman aldığı ve pahalıya mal olduğu için birçok bilgi merkezi tarafından tercih edilmez. Bu da karşılaşılan durumlarda doğru ve sağlıklı karar alma oranını düşürmektedir. Bilgi merkezleri gerçekten ne yaptıklarını bilmiyorlar ise, verdikleri hizmetlerle, gerçekleştirdikleri işlemlerle ve performansları ile ilgili kesin bir durum belirlemesi yapamazlar. Stratejik planlama, her organizasyonda olduğu gibi bilgi merkezlerinde de yönetimin en önemli görevlerinden ve başlıca karar verme alanlarından biridir. Bu nedenle bilgi merkezlerinde kullanılacak bilgi sistemi, kurumun stratejik planlama gereksinimlerini tam ve zamanlı bilgi ile destekleyecek şekilde tasarlanmalıdır.

Bilgi merkezinin amaç ve hedeflerine ulaşmasını sağlayacak olan bir plan hazırlamak için niteliksel bilgiler kadar niceliksel bilgilere de gereksinim duyulacaktır. Ancak bunu yapabilmek için kütüphaneler gerçekleştirdikleri işlemler ve vermiş oldukları hizmetler ile ilgili güvenilir ölçülerde ve geçerli, gerçekçi ve ölçülebilir standartlarda bilgilere gereksinim duyacaklardır. Bu bilgiler, aynı zamanda geçmiş dönemler ile karşılaştırılarak kütüphane performansının ölçülmesine yardımcı olacaktır.

Bilgi merkezlerinde kullanılabilecek bilgi sistemleri, bilgi merkezi yönetici- 
lerinin işlemler, hizmetler ve performans değerlendirmeleri ile ilgili kararlar almasını desteklemektedir. Kararlar için genellikle iç bilgi kaynaklarından toplanan bilgi kullanılmaktadır. Farklı kullanıcı gereksinimleri ve yöneticilerden kaynaklanan değişik yönetim anlayışlarına sahip olmaları nedeniyle, bilgi merkezlerinin gereksinim duyduğu bilgi ve aldığı kararlar da çok çeşitlidir. Bu nedenle bilgi merkezleri bünyesinde kullanılacak bilgi sistemlerinin sağlayacakları bilgi türlerinde ve oluşturulacak performans değerlendirmelerinde herhangi bir standartlaşmanın olması beklenemez. Bu açıklamalardan sonra bilgi merkezlerinde kullanılabilecek bilgi sistemlerinin amaçları ve bilgi merkezi yöneticilerine sağlayacağı yararlar şu şekilde sıralanabilir;

> Günlük rutin karar verme süreçlerinde yöneticilere ve çalışanlara destek olur.

$>$ Bilgi merkezinin her türlü kaynak kontrolünü ve mali sorumluluğunu sağlar.

$>$ Kaynak dağııımını sağlar ve kontrol eder.

> Bilgi merkezinin etkinliğini, verimliliğini ve performansını artıır.

> İç ve dış kaynaklardan elde edilen bilgiler doğrultusunda stratejik kararların alınması için raporlar üretir.

> Kısa, orta ve uzun vadeli planlamayı geliştirir.

$>$ Bilgi merkezi işlem ve hizmetlerinin ve personelin performans ölçüm işlemlerini kolaylaştırır.

Bilgi merkezlerinde son 20-25 yıldır kullanılan bilgi sistemleri günlük olarak üretilen ve bilgi merkezi içi ve dışından elde edilen verileri, toplayarak raporlara dönüştürür ve raporlar gereksinim duyan yöneticilere iletilir. Özellikle özet ve kolay anlaşılır nitelikte olan istatistiksel ve analitik bilgiler, bilgi merkezinin yönetim kademelerince tercih edilen bilgi türleridir. Bu tür bilgiler, bilgi merkezinin stratejik kararlarında ve her türlü performans değerlendirmesinde yöneticilere destek sağlar.

Bilgi merkezlerinde kullanılabilecek olan veri işlem, yönetim bilgi ve karar destek sistemleri, bilgi merkezlerinin farklı bölümlerindeki çeşitli işlemlerden elde edilen bilgileri, bilgi merkezi yöneticilerine aktarmak ile görevlidirler. Yöneticilere aktarılan bilgiler genellikle tanımlayıcı istatistiksel bilgilere dayanır. Kurulacak olan veya var olan bir bilgi sistemi, ödünç alınan kitaplar, kullanılan elektronik kaynaklar, bibliyografik bilgilendirme dersleri alan öğrenciler ve buna benzer bilgileri bir araya getirerek değerlendirir ve düzenli raporlar halinde bilgi merkezinde yapılan araştırmalara ve diğer belgelere eklemek üzere istatistiklere dönüştürülür. Tüm kullanıcılar bu sürece gayri resmi şekillerde katkıda bulunurlar. Bilgi merkezi yöneticileri resmi ve gayri resmi raporlardaki bilgileri gözden geçirip değerlendirerek, güncel veya geleceğe yönelik planlamalar yapar ve kararlar alırlar. 


\section{Kaynakça}

Abbott, C. (1994). Performance measurement in library and information services. London: ASLIB.

Adams, R. (1995). Strategic information systems and libraries. Library Management, 16 (1), 11-17.

Alkan, N. (1996). Bilgi merkezlerinin yönetiminde değerlendirmenin önemi. D. Atılgan ve S. Arslantekin (Yay. Haz.), "Türkiye'de Bilgi Merkezlerinin Yönetimi ve Sorunları" Sempozyumu bildirileri: 7 Mart 1996 Ankara içinde (ss. 22-27). Ankara: Ankara Üniversitesi Rektörlüğü.

Anameriç, H. (2003). Kütüphanelerde yönetim bilgi sistemleri ve bir model önerisi. Yayımlanmamış yüksek lisans tezi, Ankara Üniversitesi, Ankara.

Anameriç, H. (2005). Bilgi sistemleri ve yönetimde bilgi sistemlerinin kullanılması. C.C. Aktan ve I.Y. Vural (Yay. Haz.), Bilgi Çağı, Bilgi Yönetimi ve Bilgi Sistemleri içinde (ss. 121-174). Konya: Çizgi Kitabevi.

Alter, S. (1997). Information systems: A management perspective. New York: Addison Wesley Publishing Company.

Bensghir, T.K. (1996). Bilgi teknolojileri ve örgütsel değişim. Ankara: TODAIE.

Brophy, P. (1986). Management information and decision support systems in libraries. Aldershot: Gower Publishing Company Limited.

Bryson, J. (1990). Effective library and information center management. Aldershot: Gower.

Cullen, R. (1992). A bottom-up approach from down-under: Management information in your automated library system. Journal of Academic Librarianship, 18 (3), 152-157.

Cullen, R. (1990). A model of a management information system for library and information service managers. International Journal of Information and Library Research, 2 (1), 23-34.

Çelik, A. (2001). Bilgi hizmetleri ve mevzuat. Ankara: ÜNAK.

Çelik, A. (1994). Sistem kuramı ve kütüphanecilik. F. Özdemirci ve Y. Kayan (Yay. Haz.), "Prof. Dr. Berin U. Yurdadoğ’a Armağan" içinde (ss. 45-53). Ankara: Türk Kütüphaneciler Derneği.

Çimen, M. ve Ateş, M. Yönetim bilgi sistemleri. 22 Nisan 2002 tarihinde http://www.merih.net/m2/mis/wmetate23.htm adresinden erişildi.

Davis, G.B. (1985). Management information systems: Conceptual foundations structure, and development. New York: McGraw Hill.

Eco, U. (1999). Gülün adı. İstanbul: Can Yayınları.

Ferguson, S. ve Whitelaw, M. (1992). Computerized management information systems in libraries. Australian Library Journal, 41 (3 August), 184-198.

Fulweiler, R.D. ve Dugan, R.E. (2001). The role of management information systems. Journal of Academic Librarianship, 27 (5), 386-393. 
Gökçen, H. (2002). Yönetim bilgi sistemleri: Analiz ve tasarım perspektifi. Ankara: Epi Yayıncılık.

Himmetoğlu, B.A. (1971). Karar verme yeteneğini geliştirme. İzmir: Ege Üniversitesi İktisadi ve Ticari Bilimler Fakültesi.

Karakaş, S. (1991). Yönetim enformasyon sistemleri. H.S. Keseroğlu (Yay. Haz.), "Kütüphane - Enformasyon - Arşiv Alanında Yeni Teknolojiler ve Türkmarc" Sempozyumu bildirileri içinde (ss. 254-263). İstanbul: Türk Kütüphaneciler Derneği İstanbul Şubesi.

Koory, J.L. (1987). Management information systems: Planning, and decision making. Cincinnati: Southwestern Pub. Co.

Lakos, A. (1997). Library management information systems in the client server environment: A proposed new model. In Proceedings of the $2^{\text {nd }}$ Northumbria International Conference on Performance Measurement in Libraries and Information Services, 10 September 1997 (ss. 277-286). Newcastle upon Tyne: Information for the Department of Information and Library Management, University of Northumbria.

Lancaster, F.W. (1988). If you want to evaluate your library. London: Library Association.

Lucas, H. (1986). A casebook for management information systems. New York: McGraw Hill.

Lucey, T. (1987). Management information systems. Easleigh: DP Publications.

Martin, C. ve Powell, P. (1992). Information systems: A management perspective. New York: McGraw Hill.

Massie, J.L. (1983). Işletme yönetimi ( Ş. Özalp, Çev.). Eskişehir: Bayteş Yayınları.

McClure, C., Hagerty-Roach, L. ve Lindsay, R. (1989). Design of a public library management information system: A status report. Library Administration and Management, 3, 192-198.

Öztemel, E. (1998). Bilgi toplümunda yönetim bilişim sistemlerinin gelişimi. Yeni Türkiye, 21. Yüzyıl Özel Sayısı II, 1175-1181.

Paksoy, S. (1996). İşletmelerde bilgi gereksinimi ve yönetim bilişim sistemlerinin rolü. Yönetim: Istanbul Üniversitesi Iktisat Fakültesi İşletme Iktisadı Enstitüsü Dergisi, 25, 56-64.

Scott, G.M. (1986). Principles of management information systems. New York: McGraw Hill.

Uçak, N.Ö. (2000). Bilgi üzerine kuramsal bir yaklaşım. Bilgi Dünyası, 1 (1), 143-159.

Yontar, A. (1995). Kütüphane ve belge-bilgi merkezlerinde bilimsel yönetimin önemi. İstanbul: Türk Kütüphaneciler Derneği.

Ward, S. (1995). Management information systems - managing libraries. Library and Information Briefings, 60, 1-9. 